\title{
A Norwegian Penthrite Granade for Minke Whales: Hunting Trials with Prototypes and Results from the Hunt in 1984, 1985 and 1986
}

By E.O. Øen

Norwegian College of Veterinary Medicine, Oslo, Norway.

\begin{abstract}
Øen, E. O.: A Norwegian penthrite grenade for minke whales: Hunting trials with prototypes and results from the hunt in 1984, 1985 and 1986. Acta vet. scand. 1995, 36, 111121. - A penthrite grenade to replace cold harpoons in the Norwegian minke whale hunt was developed in 1983-1985. Data on survival times for 259 minke whales were collected from the trials in the 1984-86 hunting seasons, when 3 different prototypes were used. About $45 \%$ of the whales were killed instantaneously. The median survival time was $72 \mathrm{~s}$. A substantially higher percentage of instantaneous deaths was recorded for penthrite grenades than for cold harpoons. The criteria for death were cessation of flipper movement, relaxation of the mandible, or sinking without any active movement. Some animals dived before the criteria could be controlled. If the central nervous system, heart, lungs or main vessels were damaged, a high percentage of the animals died instantaneously. In most cases, hits and detonations outside the thorax and central nervous system resulted in longer survival times than hits in the thorax. Survival time increased with whale size and range for animals not killed instantaneously. Marksmanship, technical and functional reliability of equipment and hunting techniques were all crucial to a good result. Better training of gunners, improved weapons and hunting equipment and more rapid reshooting of wounded animals would reduce the proportion of long survival times.
\end{abstract}

whale hunting methods; grenade harpoon; time to death; survival time; whaling.

\section{Introduction}

A project to investigate and develop alternative killing methods to the traditional cold harpoon used in the Norwegian minke whale hunt began in 1981. After observation of hunting techniques, analysis of the hunt using the cold harpoon (Øen 1995a), trials with high-velocity projectiles (Øen 1995b) and modified cold harpoons (Øen 1994a), and evaluation of electrical harpoons (Øen 1983a), drugs (Øen 1984a), and a Japanese penthrite grenade (Øen 1994b) as possible alternatives to the cold harpoon, work on a new penthrite grenade for the Norwegian minke whale hunt began in 1983 (Øen 1994b). Some of the results of these studies have been published previously in the form of articles (Øen 1983a, Øen 1983b), or presented in unpublished reports to the International Whaling Commission (IWC) (Øen 1982, 1983c, 1984a, 1984b, 1985) and at the Workshop of Whale Hunting Techniques in IWC in 1992 (Øen 1992a, 1992b, 1992c, 1992d, 1992e).

The development of the Norwegian penthrite grenade, the introductory field trials in 1983 
and the technical specifications of the penthrite grenades used in the hunting trials in 1984-1986 are described in another article (Øen 1994b). After the introductory trials the weight was reduced and the steel jacket was replaced by a thin aluminium jacket. The ignition device and transport safety device were replaced by 2 new types of fuses, known as TAV and CLI. These were specially made for the purpose and contained both safe and arming mechanisms. In 1984, the amount of penthrite was increased from 18 to $20 \mathrm{~g}$.

After tests of grenades with the TAV and CLI safe and arming mechanisms during the 1984 hunting season, the CLI fuse was rejected. The penthrite charge was modified slightly and the amount of explosive was further increased by $2 \mathrm{~g}$ to $22 \mathrm{~g}$ (Øen 1994b). From 1985 onwards, only grenades with TAV fuses were manufactured under the name "Raufoss harpungranat" ("Raufoss Harpoon Grenade").

This article describes and analyses the results of hunting trials in 1984, using penthrite grenades with a $20 \mathrm{~g}$ penthrite charge and TAV and CLI fuses, and in 1985 and 1986, using mainly grenades with a $22 \mathrm{~g}$ penthrite charge.

\section{Materials and methods}

There were plans to manufacture about the same number of grenades with the 2 types of fuses in 1984, but as a result of delays in the production of TAV fuses, 152 grenades with TAV fuses and 1088 grenades with CLI fuses, all with $20 \mathrm{~g}$ penthrite charges, were produced by Raufoss A/S. The 2 prototypes were distributed to different boats, the traditional cold harpoon was prohibited and all gunners and licence holders were required to undergo a training course in the use of the penthrite grenade. Only vessels with approved gunners were allowed to take part in the hunt (Øen 1984b). In 1985 and 1986, it was only permit- ted to use Raufoss harpoon grenades with 22 g penthrite, and the remaining stocks of 1984 TAV grenades.

Twenty-seven official inspectors collected data from 28 vessels during the 3 seasons (1984-1986), and this information was supplemented by the author's own records from 1984. In addition to inspecting hunting operations and collecting scientific material, the inspectors were instructed to collect data on the killing of the whales, as in previous years $(\varnothing e n$ 1995a). In addition to survival time, they were asked to record data on whale length, estimated range at the moment of shooting, the angle between the shot direction and the whale's long axis, the impact point on the whale, the detonation site, necropsy findings in those organs and tissues that were damaged, and whether the whale had to be reshot either with a new grenade or with a rifle. These results were recorded on the same forms as in the 1981-83 seasons.

The time from a strike to the animal's death was recorded with a stop-watch. The time of death was, as previously, recorded as the moment at which cessation of flipper movement, relaxation of the mandible, or sinking without any active movement occurred, as established by the IWC (Anon 1980). Organ damage was inspected during butchering and shooting range and angel of the shot relative to the animal's long axis were estimated by the inspector without instrumental aid.

After the end of the hunting season in 1984 and 1985, meetings with groups of gunners were organized in order to discuss their practical experience and opinions of the new detonating grenades.

Reports were received for a total of 276 minke whales. Twelve whales for which the reports were very incomplete were excluded from the analysis. However, 5 of the 12 were reported to have died instantaneously. Six whales were 
Table 1. Percentage of minke whales dead instantaneously $(\leq 10 \mathrm{~s})$, median survival times, lower $\left(\mathrm{Q}_{1}\right)$, upper $\left(Q_{3}\right)$ quartiles and mean survival times in seconds for 259 minke whales caught with penthrite grenade after hits in different organs/tissues in hunting trials 1984-86.

\begin{tabular}{lcccrc}
\hline \multirow{2}{*}{ Tissue/organ } & $\begin{array}{c}\text { Instantaneous } \\
\text { death }(\%)\end{array}$ & Median $\left(\mathrm{Q}_{2}\right)$ & Lower quartile $\left(\mathrm{Q}_{1}\right)$ & Upper quartile $\left(\mathrm{Q}_{3}\right)$ & Mean \\
\cline { 3 - 6 } & & 0 & 0 & 0 & 11 \\
CNS & 92.6 & 0 & 0 & 0 & 27 \\
Heart & 78.7 & 0 & 0 & 100 & 83 \\
Lungs & 62.7 & 0 & 0 & 227 & 153 \\
Blood vessels & 52.8 & 487 & 300 & 827 & 493 \\
Abdomen & 15.9 & 652 & 0 & 1290 & 857 \\
Musculature & 8.4 & 72 & & 540 & 395 \\
\hline All whales & 44.8 & & 0 & & \\
\hline
\end{tabular}

lost, 1 because the harpoon line broke and 5 when the harpoon pulled out. Only 1 of these reports (18 $\mathrm{min})$ was sufficiently complete to be included, and thus 259 whales were used in the statistical analysis. Of the other 5 whales lost, 3 were so slightly wounded that they probably survived, and for 2 whales the time to death could not be established. (In an earlier report to the IWC (Øen 1992e), 7 of the whales in this material were reported as lost. However, reexamination of the data has revealed that 1 whale that died after $15 \mathrm{~s}$ had been wrongly recorded as lost and that the survival time for 1 whale that was lost after death had incorrectly been recorded as zero instead of $18 \mathrm{~min}$ ).

Statistical analysis of time to death for whales shot with $20 \mathrm{~g}$ penthrite (1984) and $22 \mathrm{~g}$ penthrite (1985-86) showed no noticeable difference in survival time between the 2 charges. The data were therefore pooled and analysed together.

The influence of the covariates shooting range and whale size on survival time was studied by Cox regression (proportional hazard) and by a combination of logistic regression for whales killed instantaneously ( $\leq 10 \mathrm{~s}$ ) and Cox regression for whales surviving $>10 \mathrm{~s}$.

\section{Results}

The survival plot for the 259 minke whales used in the analyses is shown in Figure 1. Instantaneous death ( $\leq 10 \mathrm{~s})$ was recorded for $44.8 \%$ of the whales (Table 1 ). The median survival time was $72 \mathrm{~s}$, the lower quartile was at $0 \mathrm{~s}$ and the upper quartile at $540 \mathrm{~s}$. The mean survival time was $395 \mathrm{~s}$. Thirty eight whales $(14.7 \%)$ survived more than $15 \mathrm{~min}$ and 7 whales $(2.7 \%)$ survived more than 30 min. The longest survival time recorded was $57 \mathrm{~min}$. This whale was first lost and later found and killed.

If the grenade detonated in or near the thorax, several organs were generally damaged. For animals in which the main damage was recorded in the central nervous system (CNS), heart, lungs or major blood vessels in the thorax or abdomen, the percentage of instantaneous deaths ( $\leq 10 \mathrm{~s})$ recorded was $92.6 \%$, $78.7 \%, 62.7 \%$ and $52.8 \%$ respectively (Table 1). The upper quartiles for survival time for these groups of whales were at $0,0,100$ and $227 \mathrm{~s}$ respectively. Detonations in areas which caused damage only to organs in abdomen or to the musculature $(48 \%)$ resulted in instantaneous death in only $15.9 \%$ and $8.4 \%$ of the cases, respectively. The median survival times in these cases were $487 \mathrm{~s}$ and $652 \mathrm{~s}$ and the 
upper quartiles were 827 and $1290 \mathrm{~s}$, respectively (Table 1). Reshooting with harpoons was necessary in $4.3 \%$ of the cases and rifle shots were fired at $34.4 \%$ of the whales. The whales varied in size from 5.3 to $9.2 \mathrm{~m}$ with a median length of $7.5 \mathrm{~m}$. Shooting range varied from 5 to $100 \mathrm{~m}$ (median range $25 \mathrm{~m}$ ).

The penetration abilities of the harpoon was not affected by the grenade detonation, which is triggered at a depth of $50-70 \mathrm{~cm}$ after penetration of the skin (Øen 1994b), and the harpoon went completely through the whales in $85 \%$ of the cases.

Range, whale size and the angle of the shot relative to the animal's long axis all influenced survival time, and both median and mean survival time was positively correlated with both range and whale size. Shots fired from in front (directly in front to $45^{\circ}$ to the animal's long axis) $(2 \%)$ and behind $\left(135^{\circ}\right.$-directly from behind) $(43 \%)$ produced significantly poorer results than shots from the side $\left(45-135^{\circ}\right)(55 \%)$. The median survival times for animals shot from the side and from behind were $27 \mathrm{~s}$ and $252 \mathrm{~s}$, respectively. Only 4 animals were shot from in front. One of these died instantaneously ( $\leq 10 \mathrm{~s})$. The others lived from 10 to 16 min.

Analyses of the influence of the covariates on survival time showed that the latter was significantly dependent on both covariates (shooting range and whale size). Fig. 2 illustrates the dependence between survival time and the 2 covariates. Analyses based on a combination of logistic regression for the number of whales killed and Cox regression for whales surviving $>10 \mathrm{~s}$ gave similar results. However, the fraction of the whales killed instantaneously $(\leq 10$ s) was only dependent on shooting range and not significantly on animal size $(\mathrm{p}<0.001)$. Inspection and autopsy established that detonation in or near the thoracic cavity could damage the lungs, heart and larger vessels, and that there was massive intrathoracic, subpleural haemorrhaging. Detonation in the musculature caused massive injuries to muscle tissue which was transformed into a granular, pulped, jelly-like mass without normal tissue structure up to $20-30 \mathrm{~cm}$ from the detonation site. Bleeding could be seen up to 50 $\mathrm{cm}$ from the centre. In addition, inter-fascial bleeding was noted further out in the muscle layers during dissection. The nosepiece of the grenade were found up to $1 \mathrm{~m}$ from the detonation site. If detonation occurred in the musculature dorsal to the thorax cavity, rib damage with profuse sub-pleural haemorrhaging was observed. Other bones in the vicinity of the detonation point could also be splintered. Hits in the region of the head or neck caused crushing of the cranium. Detonation in the cranial part of the abdomen led to damage of the diaphragm and liver with subserous, intraabdominal and intra-thoracic bleeding. The intestines and stomach usually suffered minor damage.

\section{Discussion}

The survival plot for the 259 minke whales for which survival times were recorded during the 1984-1986 hunting seasons shows that about $45 \%$ of the whales were killed instantaneously ( $\leq 10 \mathrm{~s}$ ) (Table 1$)$.

Whale size (length), range and angle of the shot relative to the animal's long axis all influenced survival time, but whale size was only a statistically significant factor if the whale did not die rapidly ( $\leq 10 \mathrm{~s})$. Shots from directly in front or behind gave poorer results than shots from the side because the likelihood of hitting the animal so that detonation would take place in the most vital organs was considerably lower in such cases. However, if a whale was injured in the central nervous system, heart, lungs or major blood vessels (aorta, vena cava), it generally lost consciousness and 


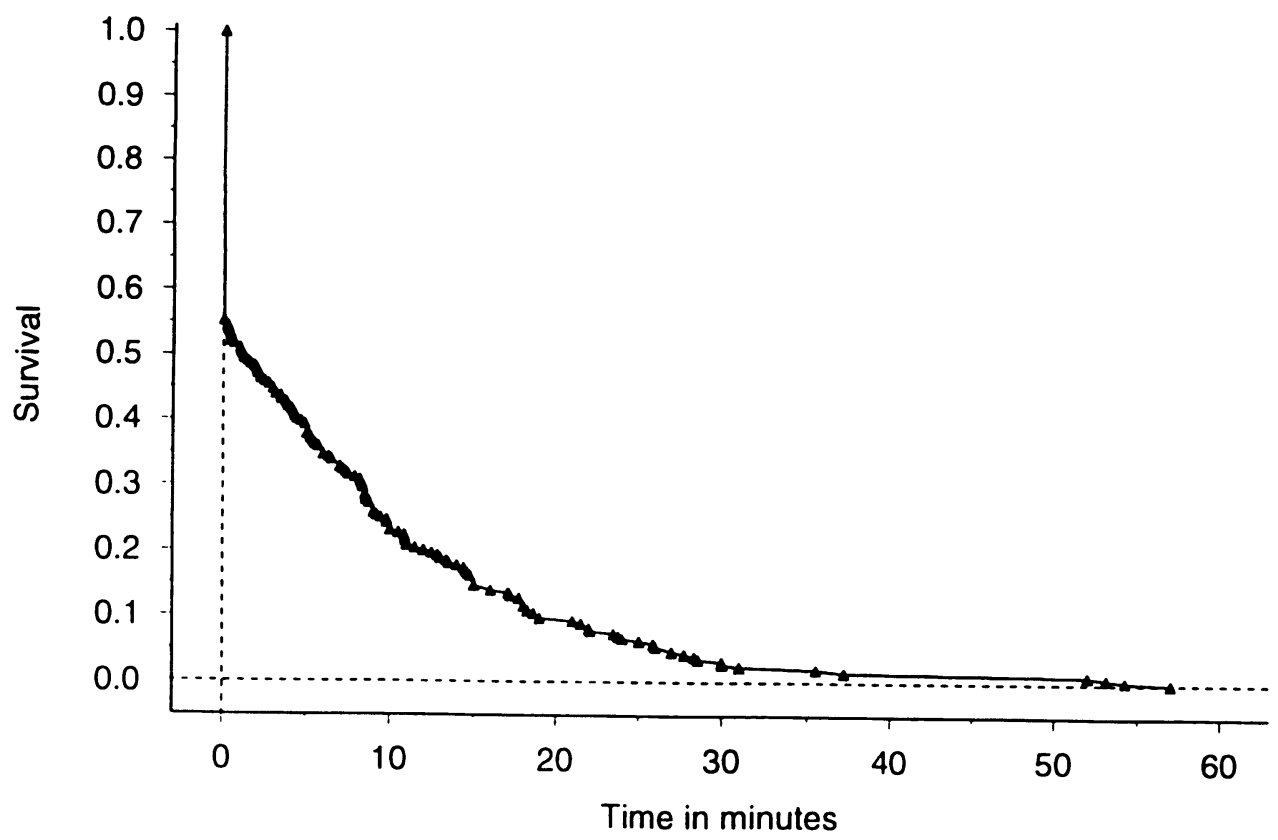

Figure 1. Survival plot for minke whales shot with prototypes of penthrite grenades in hunting trials in Norway in 1984-1986. Horizontal axis: Time in min. Vertical axis: proportion of whales still showing signs of life. The symbol $\mathbf{\Delta}$ indicates 1 or more whales.

died rapidly regardless of its size and the angle of the shot.

There are several reasons why survival time increases with animal size if the whale does not die very rapidly. In general a large animal that is injured but does not rapidly lose consciousness and die is presumed to tolerate greater stress and be less seriously affected by an injury than a smaller animal. A large whale may thus be able to make longer dives or swim further from the boat. If the whale dies during the dive, a large animal is heavier to haul in than a small one, and will be hauled in more carefully and slowly. Because the inspectors were required to make personal observations of the criteria of death before noting the time of death, such factors in some cases probably contributed to lengthen the recorded time to death. The same would be true if an animal was shot at long range. Moreover, it is well-known in other types of hunting as well that long ranges also reduce the accuracy of shooting and may result in poorer results and more wounded animals.

The criteria set out by the IWC for determination of the time of death (Anon 1980) do not take spinal reflexes into consideration. However, as described by Øen (1995a, 1994c) it is reasonable to expect that such reflexes also occur in whales and that they will contribute to lengthen the recorded time to death.

The combined results for for whales shot with penthrite grenades in the trials described in this article and with cold harpoons in 19811983 (Øen 1995a) were analysed using a combination of logistic regression for animals killed instantaneously ( $\leq 10 \mathrm{~s}$ ) and Cox regression for animals surviving longer than $10 \mathrm{~s}$, as 
Table 2. The percentages of instantaneous deaths $(\leq 10 \mathrm{~s})$ for the penthrite grenade and cold harpoon $(\emptyset$ en $1995 \mathrm{a}$ ) with primary and normalized data (based on logistic regression) where whale length $=7.0 \mathrm{~m}$ and range $=30 \mathrm{~m}$.

\begin{tabular}{lccc}
\hline Type of data & Survival time (s) & Penthrite grenade & Cold harpoon \\
\hline Primary & $\leq 10 \mathrm{~s}$ & $44.8 \%$ & $16.6 \%$ \\
Normalized & $\leq 10 \mathrm{~s}$ & $37.3 \%$ & $15.2 \%$ \\
\hline
\end{tabular}

described earlier in this article and in a previous article describing results for cold harpoons (Øen 1995a). The analysis was conducted with 3 covariates: harpoon type, range and animal length. The proportion of whales that died instantaneously was significantly higher for grenade harpoons and short ranges, but was not significantly dependent on animal size $(p=0.15)$, whereas survival times for the animals which survived $>10$ s were correlated with both size and range, but not with harpoon type.

The percentage of whales recorded as dead instantaneously or within $10 \mathrm{~s}$ was 2.7 times higher for those shot with penthrite grenades than for those shot with cold harpoons (Table 2 ). The median values for animal length and shooting range in 1984-1986 were $7.8 \mathrm{~m}$ and 25 $\mathrm{m}$, respectively, and the corresponding values for the 1981-1983 hunting seasons were $6.7 \mathrm{~m}$ and $30 \mathrm{~m}$, respectively. When the regression results were used to adjust the data for the penthrite grenade and the cold harpoon to correspond to the medians for animal length and range in the 2 periods $(7.0 \mathrm{~m}$ and $30 \mathrm{~m})$, the ratio for rapid deaths with the grenade vs the cold harpoon dropped from 2.7 to 2.5 (Table 2).

Fig. 3 which shows survival curves for both harpoon types, also indicate that the 2 killing methods differ in effectiveness and that the penthrite grenade kills more animals instantaneously than the cold harpoon. For whales not killed instantaneously, there is less difference between the 2 harpoons and the curves are more similar (Fig. 4), although penthrite grenades were still more effective during the minutes following a hit. However, this difference was not statistically significant.

A projectile damages tissues by laceration and crushing to the organs the projectile passes, and these are the primary effects of a low-velocity projectile like the cold harpoon (Øen 1994a). The use of explosives, on the other hand, enlarges the area damaged, since the very rapid expansion of gas at detonation results in pulsating pressure and shock waves that propagates supersonically in all directions and that fatally injure the organism (Sharpnack et al. 1990) in addition to the mechanical tissue damage caused by the harpoon. Irreversible damage is therefore caused in an area surrounding the detonation site, the extent of which depends on the size of the explosive charge (Stuhmiller et al. 1990), the type of tissue through which the pressure waves pass and its sensibility to these kinds of violent forces. Nervous tissue (Clemedson 1956) and gas-filled organs (Amato et al 1974), for instance, may be stretched and torn apart. Haemorraghing occurs, and in the lungs, pressure changes may give rise to alveolovenous fistulas and open communication between the air in the lungs and the circulatory system, thus causing air embolies both in coronary vessels and in basal brain arteries. According to Sharpnack et al. (1990), such embolies are the primary cause of death in blast victims. Both median and average survival times which were $72 \mathrm{~s}$ and $395 \mathrm{~s}$, respectively for 


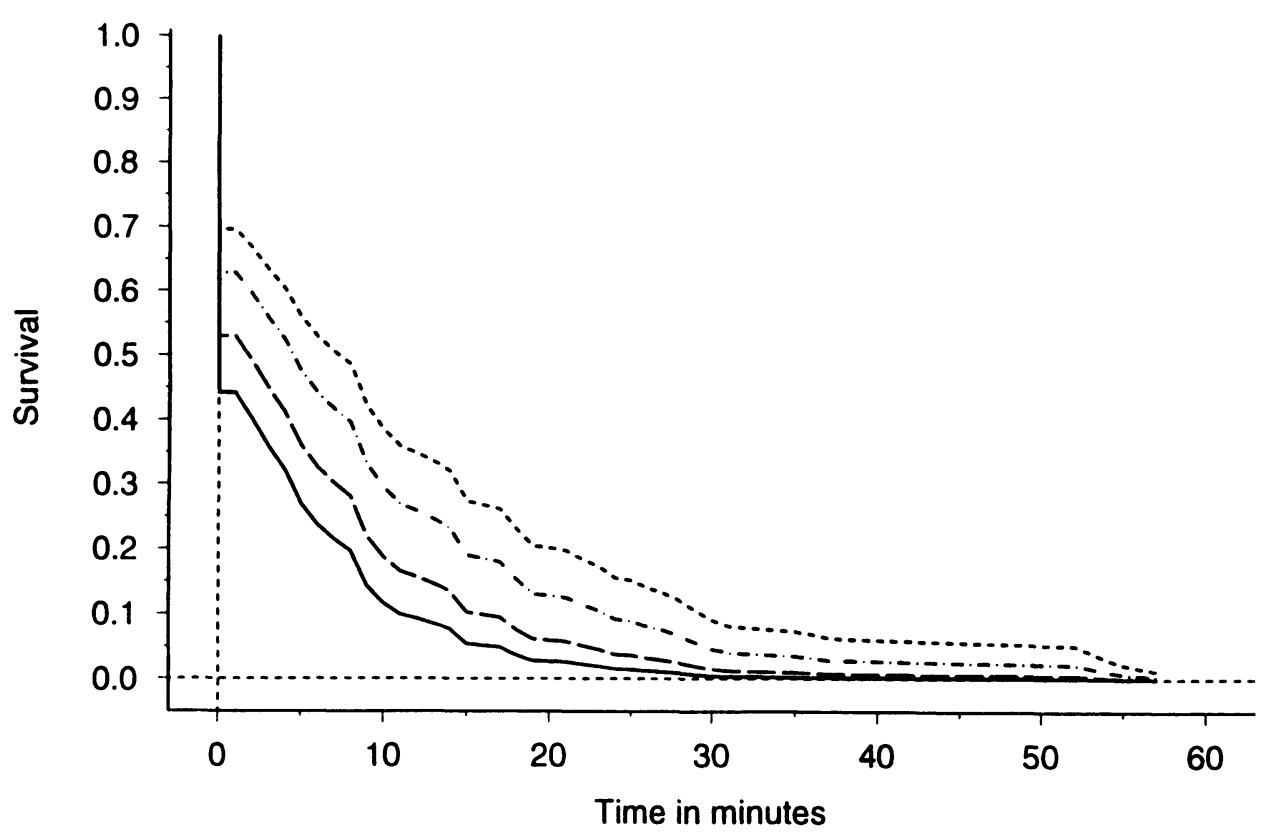

Figure 2. Estimated survival plots for minke whales after hits with penthrite grenades, based on Cox regression for selected values of the 2 covariates. Axes as in Fig. 1.

$$
\begin{aligned}
& \text { - Length }=5 \mathrm{~m}, \text { Shooting range }=10 \mathrm{~m} \\
& --: \text { Length }=5 \mathrm{~m}, \text { Shooting range }=50 \mathrm{~m} \\
& -- \text { Length }=9 \mathrm{~m}, \text { Shooting range }=10 \mathrm{~m} \\
& ---: \text { Length }=9 \mathrm{~m}, \text { Shooting range }=50 \mathrm{~m}
\end{aligned}
$$

penthrite grenades (Table 1) and $570 \mathrm{~s}$ and $680 \mathrm{~s}$, respectively for cold harpoon $(\varnothing e n$ 1995a), were considerably reduced after the introduction of the penthrite grenade. The number of wounded whales that had to be reshot with harpoons or rifles was also reduced from $17.3 \%$ with cold harpoon (Øen $1995 \mathrm{a}$ ) to $4.3 \%$ with penthrite. However, some long survival times were still recorded. There were several reasons for this, the most important being poorly placed shots which did not kill the animals rapidly. But delays before reshoting also interfered with the results. For safety reasons and to protect them from water and salt, the rifles were stored indoors unloaded and had to be fetched and loaded before use.
Whales which were weakened or unconscious occasionally revived and were able to dive or move out of range of the rifle before the gunner was ready to shoot. In 1984 a few hunters still used an outdated hunting method, inherited from earlier days, in which a wounded whale was not winched in rapidly, but instead played out to reduce the chance of losing it. Boats using this method often recorded long killing times for wounded whales. In a few cases the harpoon worked loose from the whale, and the animal had to be reshot when it was found.

During the 1984 season, reports were received for 101 minke whales shot with penthrite grenades. A total of 15 grenades malfunctioned, 


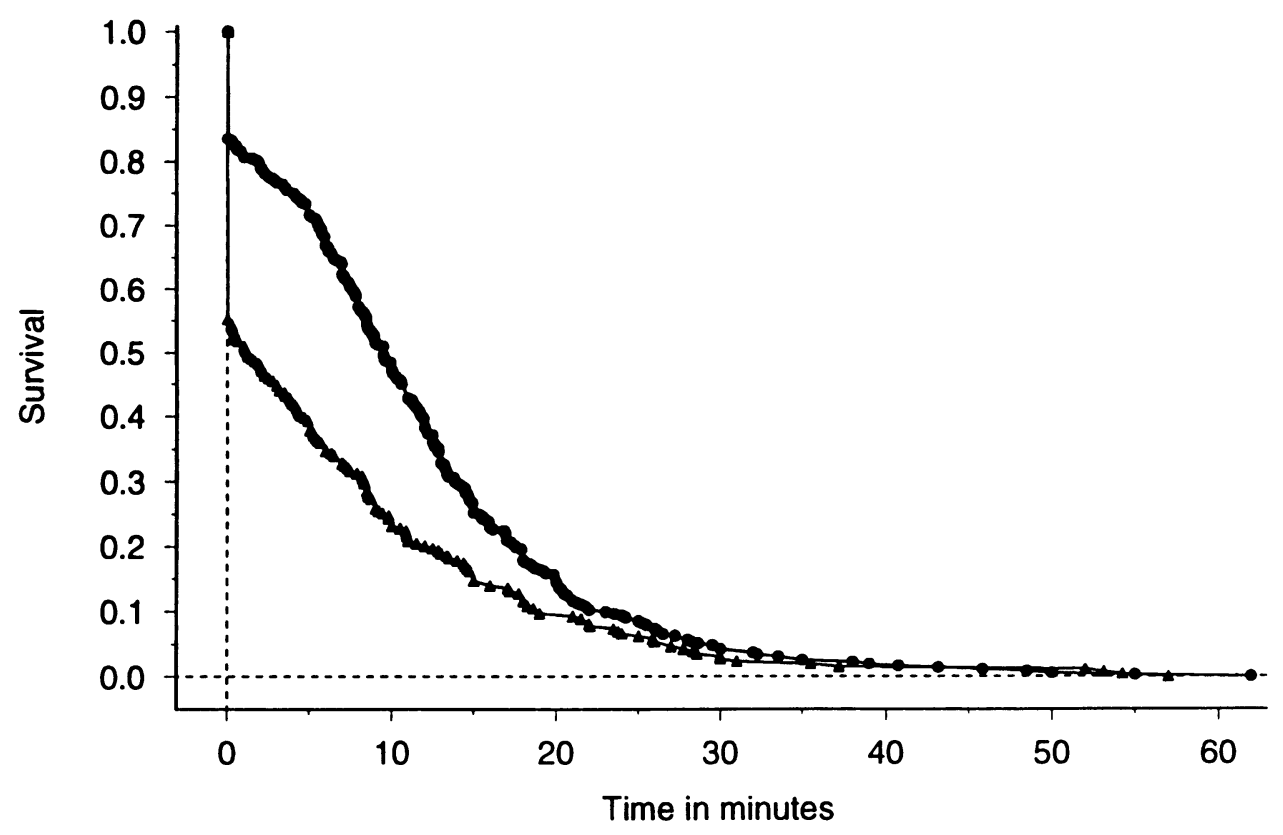

Figure 3. Survival plot for minke whales shot with prototypes of penthrite grenades in hunting trials in Norway in 1984-1986 (४) and cold harpoons $(\bullet)$ in the Norwegian minke whale hunt 1981-1983 (Øen 1995a). The symbols $\boldsymbol{\Delta}$ and $\bullet$ indicate 1 or more whales. Axes as in Fig. 1.

of which 2 had TAV fuses and 13 CLI fuses. Failure of TAV grenades was related to the penthrite charge while failures of CLI grenades were due to technical defects in the fuse, which had not been revealed during testing on land. The CLI fuses were therefore rejected for production and use after the 1984 hunting season. No grenade failures were reported during the 1985 and 1986 hunting seasons.

The trials showed that the penthrite grenade killed minke whales instantaneously or in the course of a few minutes if the grenade detonated centrally in the thorax or near the central nervous system. Detonation in the cranial part of the abdomen or in the musculature dorsal to the thorax could also result in instantaneous or very rapid death, but the effect of such hits was less reliable.
Accuracy and satisfactory hunting procedures are crucial in obtaining the best possible results. Any measures that can be taken to improve shooting accuracy and reduce the time that elapses before a wounded animal is killed will thus shorten survival times and make the hunt more humane.

Accuracy can be improved by setting high standards for gunners, weapons and projectiles. The accuracy and effect of a shot are also improved by shortening the range and by shooting only at the side of the animal, where it offers the largest possible target. This is especially important if the animal is moving when the shot is fired. To avoid cases where unconscious whales revive, or wounded ones move out of range before they can be reshot, it is important to ensure that they are brought within shooting range as quickly as possible 


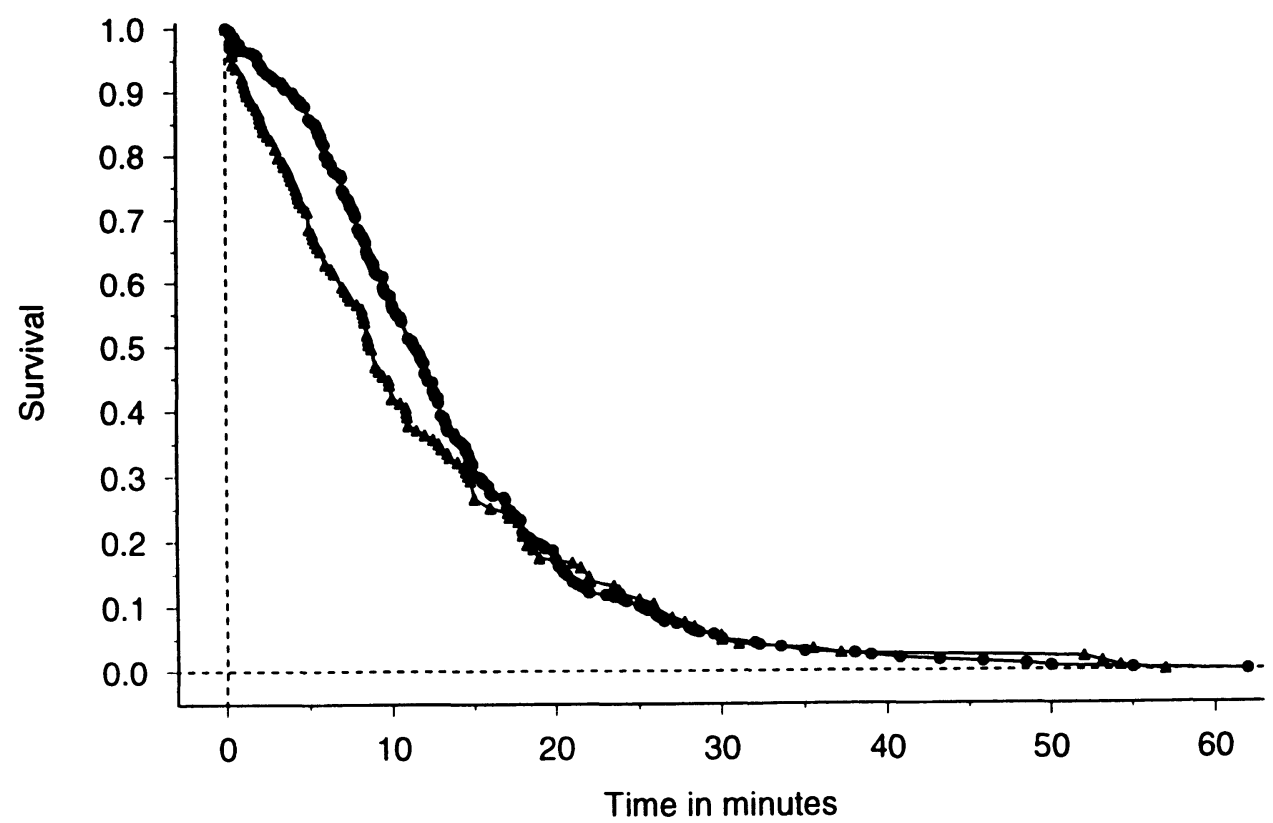

Figure 4. Survival plots for minke whales shot with prototypes of penthrite grenades (A) in the hunting trials 1984-1986 and cold harpoons (O) in the Norwegian minke whale hunt 1981-1983 (Øen 1995a). Animals killed instantaneously ( $\leq 10 \mathrm{~s})$ have been excluded from this plot. The symbols $\boldsymbol{\Delta}$ and $\boldsymbol{O}$ indicate 1 or more whales. Axes as in Fig. 1.

and that rifles are ready for use at all times. Before the scientific whaling season in 1992 and 1993 and the traditional hunt in 1993, measures were implemented with a view to improving accuracy and hunting procedures. The results will be treated in a separate article.

\section{Acknowledgements}

The author wishes to thank Dr. Torger $\emptyset$ ritsland of Institute of Marine Research in Bergen for his ad-

vices and encouragement during the field trials in 1983-84. Thanks also to Project Manager Gunnar Lybeck and his colleague Sven Jemblie of Raufoss A/S, and Director Henrik Henriksen of Henriksen Mechanical Workshop A/S for cooperation during the trials. I am also grateful to Dr. phil. Åge Jonsgård, chairman of the Advisory Group for the project in 1983-84. Thanks are due to the inspectors who collected data on the killing process in addition to their normal duties, and to Ms. Lisbeth Jensen who punched in the data from the hunt. The author wishes to thank Dr. Lars Walløe of the Department of Physiology, University of Oslo, for his help with the statistical analysis of the data, reading the manuscript and most valuable comments and advices. Thanks also to Ms Alison J. Coulthard, who corrected the English.

\section{References}

Amato JJ, Billy LJ, Lawson NS, Rich NM: High Velocity Missile Injury. An Experimental Study of the Retentive Forces of Tissue. Amer. J Surg, 1974, 127, 454-459.

Anon: Report of The Workshop on Humane Killing Techniques for Whales. Int. Whaling Commission, Cambridge, 1980, $18 \mathrm{pp}$.

Clemedson CJ: Blast injury. Physiol.Rev. 1956, 36, 336-353. 
Sharpnack DD, Johnson AJ, Phillips YY III: The Pathology of Primary Blast Injury. Textbook of Military Medicine, Part 1, Vol 5. Conventional Warfare - Ballistic, Blast, and Burn Injuries. 1990, 271-294. Publ. by The Office of the Surgeon General, Department of the Army, USA.

Stuhmiller JH, Phillips YY, Richmond DR: The Physics and Mechanisms of Primary Blast Injury. Textbook of Military Medicine, Part I, Vol 5. Conventional Warfare - Ballistic, Blast, and Burn Injuries. 1990, 241-270. Publ. by The Office of the Surgeon General, Department of the Army, USA.

$\emptyset$ en EO: Progress report on studies to increase the efficiency of killing methods in Norwegian smalltype whaling. Int. Whaling Commission, $S C / 34 / 0$ $10,1982,10 \mathrm{pp}$.

$\emptyset$ en EO: Electrical Whaling - A Review. Nord.Vet.Med. 1983a, 35, 319-323.

Øen EO: Killing Times of Minke Whales in the Norwegian Coastal Whaling in the 1981 and 1982 seasons. Nord. Vet.-Med. 1983b, 35, 314-318.

Øen EO: Progress report on research to develop more humane killing methods in Norwegian whaling. Int. Whaling Commission, $T C / 35 / H K 1$, 1983c, 9 pp.

Øen $E O$ : The use of drugs in whaling. Int. Whaling Commission, 1984a, TC/36/HK 2, 16 pp.

$\emptyset$ en EO: Progress report on research in 1983-84 to develop more humane killing methods in Norwegian whaling. Int. Whaling Commission, 1984b, TC/36/HK 1, $10 \mathrm{pp}$.

$\emptyset$ en EO: Progress report on research in 1984-85 to develop more humane killing methods in Norwegian whaling. Int. Whaling Commission, 1985, IWC/37/19, 6 pp.

$\emptyset$ en $E O$ : The Norwegian hunt of minke whales. Hunting of minke whales with modified cold harpoons in 1983. Paper prepared for the Workshop on Whale Killing Methods, Glasgow, UK, June 20-23, 1992a, IWC/44/HKW 1, 4 pp.

$\emptyset$ en EO: The Norwegian hunt of minke whales. Description and analyses of the minke whale hunt with cold harpoons in the 1981, 1982 and 1983 seasons. Paper prepared for the Workshop on Whale Killing Methods, Glasgow, UK, June 2023, 1992b, IWC/44/HKW 2, 9 pp.

$\emptyset$ en EO: The Norwegian hunt of minke whales. Hunting trials using $20 \mathrm{~mm}$ high-velocity projectiles in 1982. Paper prepared for the Workshop on Whale Killing Methods, Glasgow, UK, June 20-23, 1992c, IWC/44/HKW 3, 6 pp.
Øen EO: The Norwegian hunt of minke whales. A Norwegian penthrite grenade for minke whaling. Model description and developmental work. Paper prepared for the Workshop on Whale Killing Methods, Glasgow, UK, June 20-23, 1992d, IWC/44/HKW 4, 10 pp.

$\emptyset$ en $E O$ : A Norwegian penthrite grenade for minke whales: Hunting trials with prototypes of penthtrite grenades in 1984 and results from the 1984, 1985 and 1986 seasons. Paper prepared for the Workshop on Whale Killing Methods, Glasgow, UK, June 20-23, 1992e, IWC/44/HKW 5, 17 pp.

Øen EO: Ballistic Trials Using Harpoons with Sharp-pointed and Butt Heads and Hunting Trials Using Modified Cold Harpoons to kill Minke Whales. (1994a). In manuscript.

Øen EO: A Norwegian Penthrite Grenade for the Minke Whale Hunt. Development, Model Description and Results of Hunting Trials with Norwegian Prototypes and a Modified Japanese Penthrite Grenade in 1983. (1994b). In manuscript.

Øen EO: Hunting methods for minke whales in Norway. Results of scientific whaling in 1992 and 1993 and the traditional hunt in 1993. 1994c. In manuscript.

$\emptyset$ en EO: Description and Analysis of the Use of Cold Harpoons in the Norwegian Minke Whale Hunt in the 1981, 1982 and 1983 Hunting Seasons. Acta vet. scand. 1995a, 36, 103-110.

$\varnothing$ en $E O$ : High velocity projectiles for killing whales. Hunting trials using $20 \mathrm{~mm}$ high velocity projectiles for minke whales in 1982 . Acta vet. scand. $1995 \mathrm{~b}, 36,153-156$.

\section{Sammendrag}

Norsk pentritt harpungranat til vågehval: Fangstfors $\phi k$ med prototyper av pentrittgranater og resultater fra fangstsesongene i 1984, 1985 og 1986.

En harpungranat til vågehvalfangst, med pentritt som sprengstoff, ble utviklet i Norge i 1983-1985. Granatharpunen skulle erstatte harpuner uten sprengstoff, kaldharpuner, som ble brukt i vågehvalfangsten fram til 1984. Det ble samlet inn data for overlevelsestider fra 259 vågehval skutt med 3 forskjellige pentrittgranater i fangstsesongene 19841986. De kriterier som ble brukt for å kontrollere om hvalene var døde under datainnsamlingen, var enten at forlemmene, sveivene, lå langs siden av dyret, underkjeven hang slapt ned eller at hvalen sank uten at det kunne registreres noen aktiv bevegelse. Noen 
av dyra var døde før dette kunne kontrolleres. Resultatene viste at $45 \%$ av hvalene døde momentant $(\leq 10 \mathrm{~s})$ og at den mediane overlevelsestiden var $72 \mathrm{~s}$. Den prosentvise andelen av dyr registret momentant $\mathrm{d} \emptyset \mathrm{de}(\leq 10 \mathrm{~s})$ med pentrittgranat var 2,7 ganger h $\varnothing$ gre enn for kaldharpun. Ved skader på sentralnervesystemet, hjerte, lunger eller større blodkar, døde flesteparten av dyra momentant ( $\leq 10 \mathrm{~s})$ eller meget raskt. Treff utenfor sentralnervesystemet og thorax- området resulterte som oftest i lengre overlevelsestider enn ved treff i thorax. Dersom dyr overlevde mer enn $10 \mathrm{~s}, \emptyset \mathrm{kte}$ overlevelsestiden både med størrelsen på dyret og skuddavstanden. Dette var ikke tilfelle dersom dyrene døde momentant $(\leq 10 \mathrm{~s})$. Både den tekniske standard på fangstutstyr og våpen, skyteferdigheten og måten hvalen ble påskutt og tatt inn til båten, hadde betydning for avlivingstiden.

(Received April 18, 1994; accepted November 29, 1994).

Reprints may be requested from: E. O. Øen, Norwegian College of Veterinary Medicine. P.O. Box 8146, Dep, $\mathrm{N}-0033$ Oslo, Norway. 
